\title{
Morphological and molecular data for three species of the Microphallidae (Trematoda: Digenea) in Australia, including the first descriptions of the cercariae of Maritrema brevisacciferum Shimazu et Pearson, 1991 and Microphallus minutus Johnston, 1948
}

\author{
Olena Kudlai ${ }^{1,2,3}$, Scott C. Cutmore ${ }^{4}$ and Thomas H. Cribb ${ }^{4}$ \\ ${ }^{1}$ Institute of Parasitology, Biology Centre of the Czech Academy of Sciences, České Budějovice, Czech Republic; \\ ${ }^{2}$ Department of Parasitology, Institute of Zoology, Kyiv, Ukraine; \\ ${ }^{3}$ Laboratory of Parasitology, Nature Research Centre, Vilnius, Lithuania; \\ ${ }^{4}$ The University of Queensland, School of Biological Sciences, Brisbane, Queensland, Australia
}

\begin{abstract}
Cercariae and metacercariae of three species of the Microphallidae Travassos, 1920 were found in snails and crustaceans from tributaries of the Brisbane River, Queensland, Australia. Specimens of Maritrema brevisacciferum Shimazu et Pearson, 1991 and Microphallus minutus Johnston, 1948, which have previously been reported in Queensland, were found as cercariae in the tateid gastropod Posticobia brazieri (Smith) and as metacercariae of M. brevisacciferum in the atyid shrimp Caridina indistincta Calman and of M. minutus in the parastacid crayfish Cherax dispar Reik. Combined analysis of morphological and molecular data, based on newly generated ITS2 and partial 28S rDNA data, linked cercariae and metacercariae for both species. This is the first report of the first intermediate hosts of M. brevisacciferum and M. minutus. Infections of another unidentified microphallid metacercariae, Microphallidae gen. sp., were found in P. brazieri and C. indistincta. The sequences of metacercarial isolates from both hosts were identical. The data on the Microphallidae from Australia and species that develop in freshwater invertebrates were examined in detail.
\end{abstract}

Keywords: larval stages, life cycle, morphology, rDNA sequences, freshwaters, Brisbane River

The Microphallidae Travassos, 1920 is a large and globally distributed family of digeneans that parasitise the intestine of most vertebrate classes (Deblock 2008), but have their greatest richness in birds and mammals. The life cycles of microphallids involve gastropods, mostly marine and brackish water, as first intermediate hosts and crustaceans as second intermediate hosts. Previous studies from Australia have reported 35 microphallid species from 12 genera (Atriophallophorus Deblock et Rosé, 1964; Basantisia Pande, 1938; Endocotyle Belopol'skaya, 1952; Gynaecotyla Yamaguti, 1939; Levinseniella Stiles et Hassall, 1901; Maritrema Nicoll, 1907; Microphallus Ward, 1901; Mochliscotrema Deblock et Pearson, 1986; Pseudolevinseniella Tsai, 1955; Queenslandisia Pearson et Deblock, 1987; Rhyncostophallus Deblock et Canaris, 1997; Thulakiotrema Deblock, Williams et Evans, 1990), mainly from birds, with few species known from mammals (Hickman 1955, Deblock and Pearson 1968, 1969, Mawson et al. 1986, Shimazu and Pearson 1991).
However, despite the numerous records of microphallids in their definitive hosts, there are few records of the larval stages from intermediate hosts from this region. Metacercariae of 12 species have been found in crustaceans; one of these also has been reported from the brackish water snail, Coxiella badgerensis Johnston (see Johnston 1948, Deblock and Pearson 1968, 1969, Smith 1974, 1983, Deblock et al. 1990, Shimazu and Pearson 1991, Deblock and Canaris 1996). The only study of microphallid cercariae in Australia was by Cannon (1978), who recorded cercariae of four unidentified species in a marine cerithiid gastropod, Clypeomorus batillariaeformis Habe et Kosuge (as Cerithium moniliferum Kiener) from the Great Barrier Reef. There are no previous reports in the literature of microphallid cercariae from freshwater snails in Australia. Recently, however, cercaria of Maritrema poulini Presswell, Blasco-Costa et Kostadinova, 2014 and metacercariae of Microphallus sp. 'livelyi' were described from a freshwater snail, Potamopyrgus antipodarum

Address for correspondence: O. Kudlai, Institute of Parasitology, Biology Centre of the Czech Academy of Sciences, Branišovská 31 , 370 05 České Budějovice, Czech Republic. Phone: +420 387775437; Fax: +420-38-5310388; E-mail: olena.kudlai@gmail.com 
Table 1. Host data, geographical origin and GenBank accession numbers for digenean species used in phylogenetic analyses.

\begin{tabular}{|c|c|c|c|c|}
\hline Species & Host & Country & $\begin{array}{l}\text { GenBank } \\
\text { No. 28S }\end{array}$ & Reference \\
\hline \multicolumn{5}{|l|}{ Maritrema Nicoll, 1907} \\
\hline M. arenaria Hadley et Castle, 1940 & $\begin{array}{l}\text { Semibalanus balanoides } \\
\text { (Linnaeus) }\end{array}$ & Belfast Lough, Northen Ireland & AY220629 & Tkach et al. (2003) \\
\hline $\begin{array}{l}\text { M. brevisacciferum Shimazu et Pearson, } \\
1991\end{array}$ & Posticobia brazieri (Smith) & Brisbane, Australia & KT355819 & Present study \\
\hline M. brevisacciferum & Caridina indistincta Calman & Brisbane, Australia & KT355818 & Present study \\
\hline M. eroliae Yamaguti, 1939 & $\begin{array}{l}\text { Clypeomorus bifasciatus } \\
\text { (Sowerby) }\end{array}$ & Shuwaikh Bay, Kuwait & JF826247 & Al-Kandari et al. (2011) \\
\hline M. heardi (Kinsella et Deblock, 1994) & Oryzomys palustris (Harlan) & Florida, USA & AY220632 & Tkach et al. (2003) \\
\hline M. neomi Tkach, 1998 & Neomys anomalus Cabrera & Zakarpatska Region, Ukraine & AF151927 & Tkach et al. (2000) \\
\hline $\begin{array}{l}\text { M. novaezealandense Martorelli, } \\
\text { Fredensborg, Mouritsen et Poulin, } 2004\end{array}$ & $\begin{array}{l}\text { Zeacumantus subcarinatus } \\
\text { (Sowerby) }\end{array}$ & $\begin{array}{l}\text { Portobello Bay, Dunedin, New } \\
\text { Zealand }\end{array}$ & KJ144178 & Presswell et al. (2014) \\
\hline M. oocysta (Lebour, 1907) & Hydrobia ulvae (Pennant) & Belfast Lough, Northen Ireland & AY220630 & Olson et al. (2003) \\
\hline $\begin{array}{l}\text { M. poulini Presswell, Blasco-Costa } \\
\text { et Kostadinova, } 2014\end{array}$ & $\begin{array}{l}\text { Paracorophium excavatum } \\
\text { (Thomson) }\end{array}$ & $\begin{array}{l}\text { Lake Waihola, Waihola, New } \\
\text { Zealand }\end{array}$ & KJ144177 & Presswell et al. (2014) \\
\hline M. prosthometra Deblock et Heard, 1970 & Oryzomys palustris & Cedar Key, Florida, USA & AY220631 & Tkach et al. (2003) \\
\hline M. subdolum Jägerskiöld, 1909 & Hydrobia ulvae & $\begin{array}{l}\text { Kandalaksha Bay, White Sea, } \\
\text { Russia }\end{array}$ & HM584135 & Galaktionov et al. (2012) \\
\hline $\begin{array}{l}\text { M. deblocki Presswell, Blasco-Costa } \\
\text { et Kostadinova, } 2014\end{array}$ & Anas platyrhynchos Linnaeus & $\begin{array}{l}\text { Karitane Estuary, Otago, New } \\
\text { Zealand }\end{array}$ & KJ144173 & Presswell et al. (2014) \\
\hline \multicolumn{5}{|l|}{ Microphallus Ward, 1901} \\
\hline M. abortivus Deblock, 1974 & Hydrobia ulvae & Belfast Lough, Northen Ireland & AY220626 & Tkach et al. (2003) \\
\hline M. basodactylophallus (Bridgman, 1969) & Oryzomys palustris & Cedar Key, Florida, USA & AY220628 & Tkach et al. (2003) \\
\hline M. fusiformis Reimer, 1963 & Hydrobia ulvae & Belfast Lough, Northen Ireland & AY220633 & Tkach et al. (2003) \\
\hline M. minutus Johnston, 1948 & Posticobia brazieri & Brisbane, Australia & KT355823 & Present study \\
\hline M. minutus & Cherax dispar Reik & Brisbane, Australia & KT355822 & Present study \\
\hline M. primas (Jägerskiöld, 1908) & Hydrobia ulvae & Belfast Lough, Northen Ireland & AY220627 & Tkach et al. (2003) \\
\hline M. similis (Jägerskiöld, 1900) & Carcinus maenas (Linnaeus) & Belfast Lough, Northen Ireland & AY220625 & Tkach et al. (2003) \\
\hline M. triangulatus Galaktionov, 1984 & $\begin{array}{l}\text { Somateria mollissima Bona- } \\
\text { parte et Gray }\end{array}$ & $\begin{array}{l}\text { Yamskaya Bay, Sea of Okhotsk, } \\
\text { Russia }\end{array}$ & HM584139 & Galaktionov et al. (2012) \\
\hline Microphallus sp. & Somateria mollissima & $\begin{array}{l}\text { Cape Taygonos, Sea of } \\
\text { Okhotsk, Russia }\end{array}$ & HM584142 & Galaktionov et al. (2012) \\
\hline Microphallus sp. & $\begin{array}{l}\text { Austrolittorina cincta (Quoy et } \\
\text { Gaimard) }\end{array}$ & t Weller's Rock, New Zealand & KJ868217 & O’Dwyer et al. (2014) \\
\hline Microphallidae gen. sp. & Posticobia brazieri & Brisbane, Australia & KT355820 & Present study \\
\hline Microphallidae gen. sp. & Caridina indistincta & Brisbane, Australia & KT355821 & Present study \\
\hline \multicolumn{5}{|l|}{ Outgroup } \\
\hline $\begin{array}{l}\text { Paralecithodendrium chilostomum } \\
\text { (Mehlis, 1831) }\end{array}$ & Viviparus viviparus (Linnaeus) & Kyiv, Ukraine & KJ126725 & Kudlai et al. (2015) \\
\hline
\end{tabular}

(Gray), in New Zealand (Hechinger 2012, Presswell et al. 2014).

During a study of parasites infecting freshwater invertebrates of the Brisbane River and its tributaries, specimens of the tateid gastropod Posticobia brazieri (Smith) and the crustaceans Caridina indistincta Calman and Cherax dispar Reik were found to be naturally infected with the larval stages of species belonging to the family Microphallidae. Detailed morphological study and comparative analyses based on newly-obtained sequences of the nuclear ribosomal ITS2 region and partial 28S rDNA gene revealed the presence of three species, identified as Maritrema brevisacciferum Shimazu et Pearson, 1991, Microphallus minutus Johnston, 1948 and Microphallidae gen. sp. Metacercariae of $M$. brevisacciferum and $M$. minutus have previously been recorded in prawns Caridina nilotica (Roux) and crayfish $C$. dispar, respectively, from the Brisbane River (Shimazu and Pearson 1991), but the first intermediate host of neither species has been reported. This paper provides morphological descriptions and genetic characterisation of the larval stages of the three microphallid species discovered from the Brisbane River and its tributaries.

\section{MATERIALS AND METHODS}

\section{Sample collection}

Sampling of snails and crustaceans was carried out in February 2015 at three sites on tributaries of the Brisbane River: Moggill Creek (2730'16"S; $\left.152^{\circ} 55^{\prime} 50^{\prime \prime} \mathrm{E}\right)$, Churchbank Weir $\left(27^{\circ} 46^{\prime} 16^{\prime \prime S}\right.$; $\left.152^{\circ} 41^{\prime} 02^{\prime \prime E}\right)$ and Fairnie Brook $\left(27^{\circ} 28^{\prime} 58^{\prime \prime S}\right.$; $\left.152^{\circ} 40^{\prime} 04^{\prime \prime E}\right)$. A total of 4480 Posticobia brazieri were examined. Additionally, 38 Caridina indistincta, 34 Macrobrachium tolmerum Reik and one Cherax dispar were examined from Moggill Creek and Churchbank Weir.

\section{Morphological data}

In the laboratory, snails were placed individually in plastic containers with fresh pond water and examined daily for the presence of naturally emerged cercariae. Infected gastropods were subsequently dissected to determine the nature of the intramolluscan stages. Cercariae were examined alive unstained and then following staining with neutral red, under slight coverslip pressure. Photomicrographs of live isolates (cercariae and metacercariae) were taken with a Nikon Digital Sight DS-LI digital camera (Nikon Corporation, Tokyo, Japan) mounted on an Olympus BH-2 microscope. Measurements were taken from pictures of live material 
with SPOT ${ }^{\mathrm{TM}}$ imaging software. All measurements are in micrometres and are given as a range followed by the mean and the number of measurements taken (n) in parentheses. Drawings are based on digital images of live cercariae and metacercariae.

\section{Molecular data}

Total genomic DNA was isolated using phenol/chloroform extraction techniques (Sambrook and Russell 2001). The partial D1-D3 fragment of the 28S nuclear ribosomal DNA region was amplified using the primers LSU5 (5'-TAGGTCGACCCGCTGAAYTTAAGC-3'; Littlewood et al. 2000) and 1500R (5'-GCTATCCTGAGGGAAACTTCG-3'; Snyder and Tkach 2001) and the ITS2 region was amplified using the primers 3S (5'-GGTACCGGTGGATCACGTGGCTAGTG-3'; Bowles et al. 1993) and ITS2.2 (5'-CCTGGTTAGTTTCTTTTCCTCCGC-3'; Cribb et al. 1998). PCR for both the $28 \mathrm{~S}$ and ITS 2 regions was performed with a total volume of $20 \mu \mathrm{l}$ consisting of $5 \mu \mathrm{l}$ of $5 \times$ MyTaq Reaction Buffer (Bioline), $0.75 \mu \mathrm{l}$ of each primer (10 pmols), $0.25 \mu \mathrm{l}$ of Taq polymerase (Bioline MyTaq ${ }^{\mathrm{TM}}$ DNA Polymerase), $2 \mu \mathrm{l}$ of DNA template (approximately $10 \mathrm{ng}$ ), made up to $20 \mu \mathrm{l}$ with Invitrogen $^{\mathrm{TM}}$ ultraPURETM distilled water. Amplification was carried out on a MJ Research PTC-150 thermocycler.

The following profile was used to amplify the $28 \mathrm{~S}$ region: an initial $95^{\circ} \mathrm{C}$ denaturation for $4 \mathrm{~min}$, followed by 30 cycles of $95^{\circ} \mathrm{C}$ denaturation for $1 \mathrm{~min}, 56^{\circ} \mathrm{C}$ annealing for $1 \mathrm{~min}, 72^{\circ} \mathrm{C}$ extension for $2 \mathrm{~min}$, followed by a single cycle of $95^{\circ} \mathrm{C}$ denaturation for $1 \mathrm{~min}, 55^{\circ} \mathrm{C}$ annealing for $45 \mathrm{~s}$ and a final $72^{\circ} \mathrm{C}$ extension for $4 \mathrm{~min}$. The following profile was used to amplify the ITS2 region: an initial single cycle of $95^{\circ} \mathrm{C}$ denaturation for $3 \mathrm{~min}$, $45^{\circ} \mathrm{C}$ annealing for $2 \mathrm{~min}, 72^{\circ} \mathrm{C}$ extension for $90 \mathrm{~s}$, followed by 4 cycles of $95^{\circ} \mathrm{C}$ denaturation for $45 \mathrm{~s}, 50^{\circ} \mathrm{C}$ annealing for $45 \mathrm{~s}$, $72{ }^{\circ} \mathrm{C}$ extension for $90 \mathrm{~s}$, followed by 30 cycles of $95^{\circ} \mathrm{C}$ denaturation for $20 \mathrm{~s}, 52^{\circ} \mathrm{C}$ annealing for $20 \mathrm{~s}, 72^{\circ} \mathrm{C}$ extension for $90 \mathrm{~s}$, followed by a final $72^{\circ} \mathrm{C}$ extension for $5 \mathrm{~min}$.

Amplified DNA was purified using a Bioline ISOLATE II PCR and Gel Kit according to the manufacturer's protocol. Cycle sequencing of purified DNA was carried out using ABI Big Dye $^{\mathrm{TM}}$ V.3.1 chemistry following the manufacturer's recommendations, using the same primers used for PCR amplification as well as the additional $28 \mathrm{~S}$ rDNA primers $300 \mathrm{~F}$ (5'-CAAGTACCGTGAGGGAAAGTT-3'; Littlewood et al. 2000) and ECD2 (5'-CTT GGTCCGTGTTTCAAGACGGG-3'; Littlewood et al. 2000), and the additional ITS2 primer GA1 (5'-AGAACATCGACATCTTGAAC-3'; Anderson and Barker 1998). Cycle sequencing was carried out at the Australian Genome Research Facility using an AB3730xl capillary sequencer. Sequencher ${ }^{\mathrm{TM}}$ version 4.5 (GeneCodes Corp.) was used to assemble and edit contiguous sequences. GenBank accession numbers for taxa sequenced in this study are shown in Table 1.

Newly generated 28S rDNA data from larval stages of Maritrema brevisacciferum, Microphallus minutus and Microphallidae gen. sp., together with sequences of other microphallids available on GenBank, were used in phylogenetic analyses (Table 1). A sequence of the lecithodendriid Paralecithodendrium chilostomum (Mehlis, 1831) (KJ126725) was used as an outgroup based on the topologies in the phylogenetic trees of the Digenea published by Olson et al. (2003).

Sequences were aligned using ClustalW as implemented in the BioEdit program, version 7.0.1 (Hall 1999). The alignment was then trimmed to the length of the shortest sequence. Phylogenetic analysis was carried out using Bayesian inference (BI) and Maximum Likelihood (ML) analyses. The nucleotide substitution model, the general time reversible model, with estimates of invariant sites and gamma distributed among-site rate variation $(\mathrm{GTR}+\mathrm{I}+\mathrm{G})$ was determined using jModelTest 2 software (Darriba et al. 2012). BI analysis was performed using MrBayes software (ver. 3.2.3) (Ronquist et al. 2012) run on the CIPRES portal (Miller et al. 2010) with the following nucleotide substitution model settings: lset nst $=6$, rates $=$ invgamma, samplefreq $=100$, ncat $=4$, shape $=$ estimate, inferrates $=$ yes and basefreq $=$ empirical. Markov chain Monte Carlo (MCMC) chains were run for 10000000 generations, log-likelihood scores were plotted and only the final $75 \%$ of trees were used to produce the consensus trees by setting the 'burn-in' parameter at 2500 . This number of generations was considered sufficient because the standard deviation dropped well below 0.01 at the end of the run. ML analysis was performed using PhyML version 3.0 (Guindon et al. 2010) run online on the ATGC bioinformatics platform, Next generation Sequencing [http://www.atgc-montpellier.fr/ngs]. Nodal support in the Maximum Likelihood analysis was estimated by performing 100 bootstrap pseudoreplicates. Trees were visualised using the FigTree ver. 1.4 software (Rambaut 2012).

\section{RESULTS}

Examination of 4480 individuals of Posticobia brazie$r i$ from the Brisbane River tributaries at three localities in Queensland revealed infections with digeneans from eight families. Nine infections consistent with species of the family Microphallidae were identified based on naturally emerged cercariae. Metacercariae of Maritrema brevisacciferum and Microphallidae gen. sp. were found in Caridina indistincta; metacercariae of Microphallidae gen. sp. were also found in huge numbers in the tissues of a single P. brazieri. Metacercariae of Microphallus minutus were recovered from Cherax dispar. No specimen of Macrobrachium tolmerum was infected by digenean metacercariae. Descriptions of the mature cercariae and metacercariae of these digeneans are provided below.

\section{Family Microphallidae Travassos, 1920}

Genus Maritrema Nicoll, 1907

\section{Maritrema brevisacciferum Shimazu et Pearson, 1991}

Fig. 1

Description of cercaria (based on 20 live naturally emerged specimens from $P$. brazieri from Moggill Creek): Small monostome xiphidiocercariae developing in elongate sporocysts. Body elongate-oval, 82-119 $(98 ; \mathrm{n}=19)$ long, with maximum width at midbody 38-59 (48). Tegument covered with minute spines. Tail simple, 69-107 (98; $\mathrm{n}=13)$ long, $12-15(13 ; \mathrm{n}=15)$ wide at base, slightly shorter than body. Oral sucker subterminal, spherical, muscular, 17-25 × 18-25 $(21 \times 22)$. Stylet straight, lanceolate, slightly wider at base, $14-18 \times 2.5-3(16 \times 2.9)$ with lateral pointed thickenings at first third of length. Digestive system not developed. Penetration gland-cells in two pairs, 

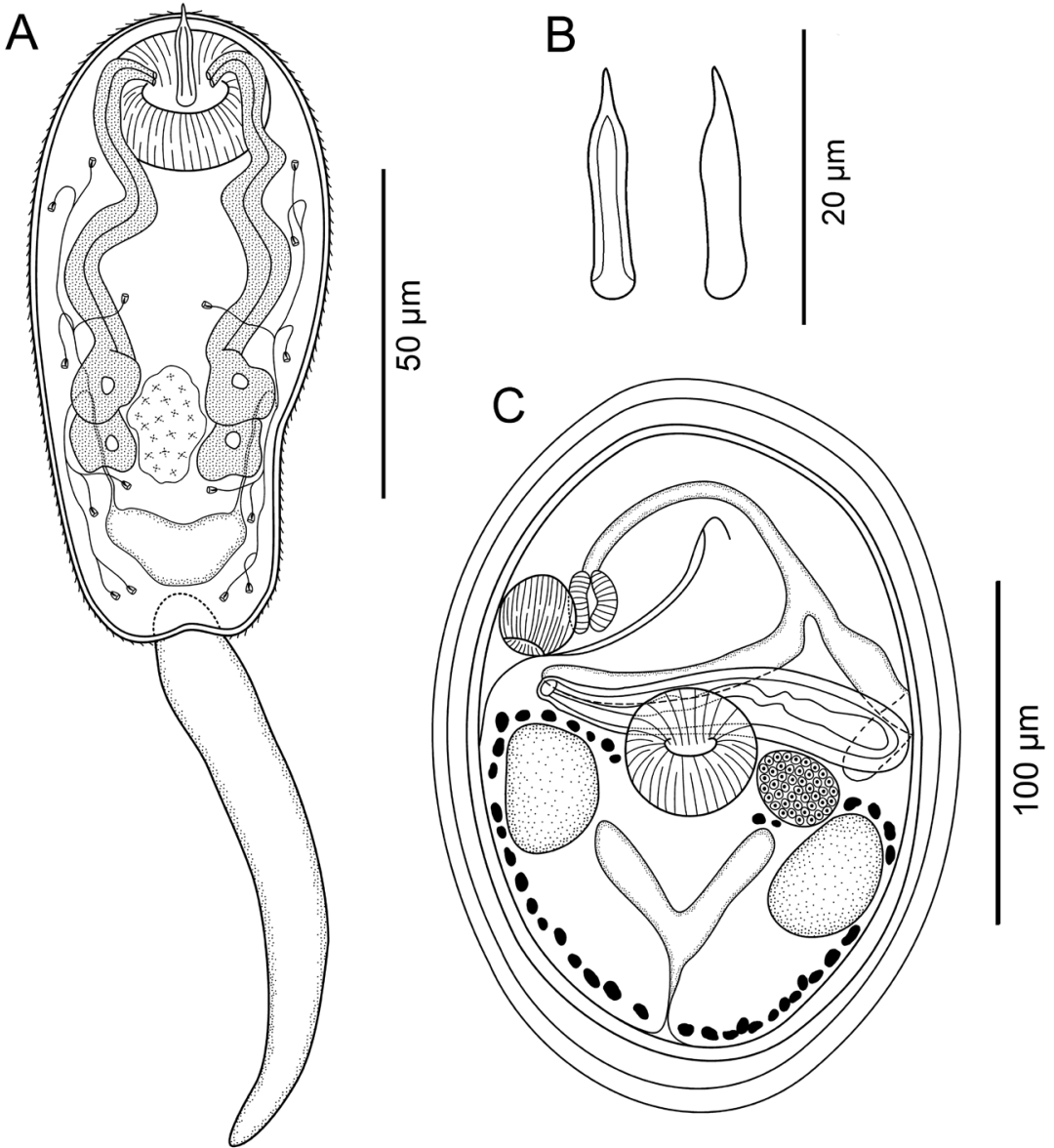

Fig. 1. Maritrema brevisacciferum Shimazu et Pearson, 1991. A - cercaria from Posticobia brazieri (Smith), ventral view; B - stylet, ventral and lateral view; $\mathbf{C}$ - metacercaria from Cardina indistincta Calman.

filled with secretory material in form of small granules, located in third quarter of body, at 52-90 $(66 ; \mathrm{n}=18)$ from anterior extremity of body. Posterior pairs of penetration gland-cells not observed. Ducts open ventrolaterally to stylet. Genital primordium an oval mass of cells in posterior third of body. Excretory vesicle Y-shaped. Flame-cell formula $2[(2+2)+(2+2)]=16$.

Description of metacercaria (based on 28 live encysted specimens from Moggill Creek - 18 and Churchbank Weir - 10): Metacercaria in elongate-oval cyst, 161-215 $\times$ 113-141 (186 × 126). Cyst wall consisting of two hyaline layers; third, external layer also present, probably formed by encapsulation process induced by host haematocytes. Entire tegument covered with dense spines. Oral sucker subterminal; ventral sucker, 33-36 × 35-38 $(35 \times 37$; $\mathrm{n}=6$ ); oesophagus long; caeca short, reaching to ventral sucker. Reproductive system well-developed. Testes two, lateral, oval, symmetrical; left testis 30-35 × 29-31 (33 × $30 ; \mathrm{n}=4)$, right testis $31-39 \times 28-32(\mathrm{n}=2)$. Cirrus-sac long, 93-106 (99; 6), occupying almost entire body width, maximum width at base $16-28(24 ; \mathrm{n}=6)$, with thick muscular wall located between intestinal caeca and ventral sucker, enclosing seminal vesicle and ejaculatory duck. Seminal vesicle elongate, occupies one third of length of cirrus-sac. Ejaculatory duct long, convoluted. Ovary oval, 26-30 × 21-27 $(28 \times 24 ; n=4)$. Vitellarium in hindbody, comprised of few small follicles forming two symmetrical ribbons encircling testes; ribbons converge anteriorly to testes, interrupted posteriorly. Excretory vesicle Y-shaped; arms reach to mid-level of testes; pore terminal.

First intermediate host: Posticobia brazieri (Smith) (Gastropoda: Tateidae).

Locality: Moggill Creek and Fairnie Brook, Queensland, Australia.

Prevalence of emergence: 1 of 2160 (Moggill Creek), 7 of 2080 (Fairnie Brook).

Second intermediate host: Caridina indistincta Calman (Decapoda: Atyidae).

L o c a lity: Moggill Creek and Churchbank Weir, Queensland, Australia.

Prevale n c e: $71 \%$ (Moggill Creek), 42\% (Churchbank Weir). Representative sequences: Cercaria KT355819 (28S rDNA), KT355825 (ITS2), metacercaria KT355818 (28S rDNA), KT355824 (ITS2).

Remarks. Specimens of the metacercaria described above possess a cirrus-sac enclosing the cirrus, seminal vesicle and ejaculatory duct, which is characteristic of the Maritrematinae Nicoll, 1907 (see Deblock 2008). This subfamily is represented in Australia by nine species of the genus Maritrema; three of these have been recorded in second intermediate hosts (Table 2).

A comparison with the known metacercariae from fresh waters in Australia shows striking similarities between the 


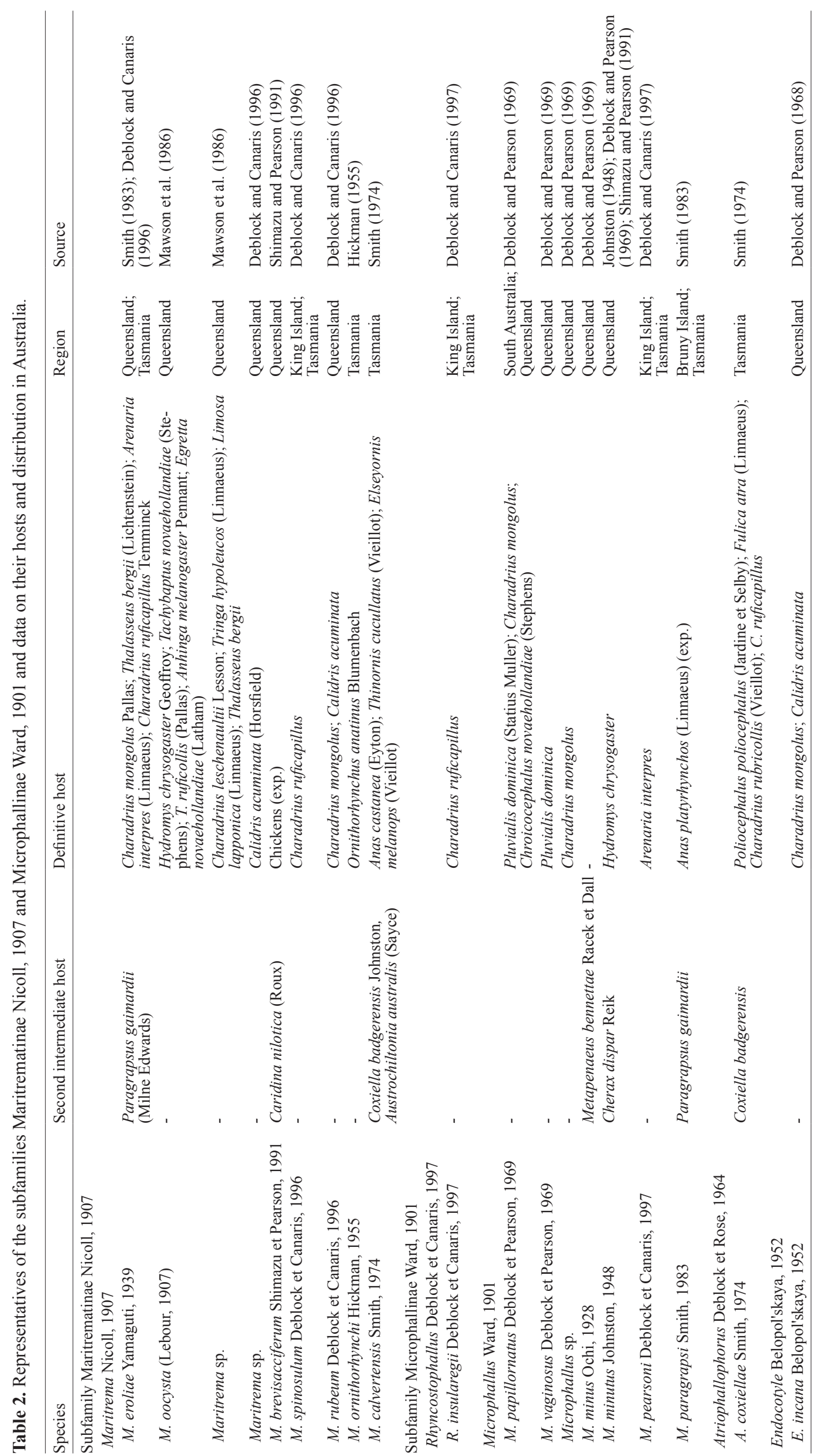


Table 3. Comparative metrical data for metacercariae of Maritrema brevisacciferum Shimazu et Pearson, 1991 and Microphallus minutus Johnston, 1948. Measurements are in micrometres.

\begin{tabular}{|c|c|c|c|c|c|c|}
\hline \multirow[t]{2}{*}{$\begin{array}{l}\text { Species } \\
\text { Host } \\
\text { Source }\end{array}$} & \multicolumn{2}{|c|}{$\begin{array}{c}\text { Maritrema brevisacciferum } \\
\text { Caridina indistincta } \text { Calman } \\
\text { Present study }\end{array}$} & \multirow{2}{*}{$\begin{array}{c}\text { Maritrema brevisacciferum } \\
\text { Caridina nilotica (Roux) } \\
\text { Shimazu and Pearson (1991) } \\
\text { Range }\end{array}$} & \multicolumn{2}{|c|}{$\begin{array}{l}\text { Microphallus minutus } \\
\text { Cherax dispar Reik } \\
\text { Present study }\end{array}$} & \multirow{2}{*}{$\begin{array}{c}\text { Microphallus minutus } \\
\text { Cherax dispar } \\
\text { Shimazu and Pearson (1991) } \\
\text { Range }\end{array}$} \\
\hline & Range & Mean & & Range & Mean & \\
\hline Cyst length & $161-215$ & 186 & $150-230$ & $238-320$ & 297 & $310-540$ \\
\hline Cyst width & $113-141$ & 126 & $120-140$ & $235-297$ & 278 & $290-540$ \\
\hline Body length & - & - & $232-288$ & - & - & $376-408 *$ \\
\hline Body width & - & - & $144-168$ & - & - & $256-312 *$ \\
\hline Oral sucker length & - & - & $24-27$ & 50 & - & $32-40 *$ \\
\hline Oral sucker width & - & - & $30-32$ & 55 & - & $51-56^{*}$ \\
\hline Pharynx length & - & - & $17-19$ & 18 & - & $22-24 *$ \\
\hline Pharynx width & - & - & $11-13$ & 15 & - & $16-17 *$ \\
\hline Oesophagus length & - & - & $19-29$ & - & - & $48-80 *$ \\
\hline Ventral sucker length & $33-36$ & 35 & $33-40$ & 44 & - & - \\
\hline Ventral sucker width & $35-38$ & 37 & $40-43$ & 55 & - & $51-56^{*}$ \\
\hline Right testis length & $30-35$ & - & $33-40$ & $77-85$ & 82 & $72-96 *$ \\
\hline Right testis width & $29-31$ & - & $32-36$ & $49-60$ & 55 & $40-64 *$ \\
\hline Left testis length & $31-39$ & 33 & $33-40$ & $80-83$ & 81 & $72-96^{*}$ \\
\hline Left testis width & $28-32$ & 30 & $32-36$ & $58-60$ & 59 & $40-64 *$ \\
\hline Cirrus-sac length & $93-106$ & 99 & $96-104$ & - & - & $45-76^{* *}$ \\
\hline Cirrus-sac width & $21-27$ & 24 & $24-29$ & - & - & $40 * *$ \\
\hline Ovary length & $26-30$ & 28 & 32 & $61-70$ & 64 & $56-72 *$ \\
\hline Ovary width & $21-27$ & 24 & $29-40$ & $38-45$ & 41 & $48-80^{*}$ \\
\hline
\end{tabular}

* measurements for two-day-old adults; ** measurements of the phallus.

present metacercaria and that of $M$. brevisacciferum described by Shimazu and Pearson (1991) from C. nilotica in the Brisbane River with both possessing the characteristic oval shape and size of cyst, the presence of a long cirrus-sac with a thick muscular wall, long ejaculatory duct and both parasitising freshwater prawns, Caridina spp. The metrical data for the present metacercariae generally fall within the range for $M$. brevisacciferum, but include slightly smaller measurements for testes and ovary, and smaller lower limits for the width of cyst, width of the ventral sucker and length and width of the cirrus-sac (see Table 3 ).

Comparative sequence analysis of cercarial isolates from the snail $P$. brazieri and metacercarial isolates from C. indistincta revealed identical sequences for each of the 28S and ITS2 rDNA regions (Fig. 4). This result allowed us to assign this cercaria to M. brevisacciferum. This species was described from experimentally infected chickens (Shimazu and Pearson 1991) and has not yet been recorded from a natural definitive host. This is the first report of the first intermediate hosts of $M$. brevisacciferum and the first description of its cercaria.

Genus Microphallus Ward, 1901

Microphallus minutus Johnston, 1948

Fig. 2

Description of cercaria (based on 18 live naturally emerged specimens): Small monostome xiphidiocercariae developing in elongate sporocysts. Body elongate-oval, 87-122 (101) long, with maximum width at level of oral sucker, 40-66 (53). Tegument covered with minute spines. Tail simple, 60-96 (84) long, 10-13 (11) wide at base, shorter than body. Oral sucker subterminal, muscular, subspherical, 23-30 × 20-31 $(26 \times 27 ; n=15)$. Stylet straight, sharply-pointed, $16-17 \times 3-4(16 \times 3.2 ; \mathrm{n}=16)$, slightly wider at level of lateral pointed thickenings at about midlength. Digestive system not developed. Penetration glandcells in four pairs: two anterior pairs filled with secretory material in form of large granules, extend to slightly posterior to oral sucker; two posterior pairs equatorial, filled with secretory material in form of small granules; gland ducts extend around oral sucker and open ventrolaterally to stylet. Genital primordium an oval mass of cells in posterior third of body. Excretory vesicle V-shaped. Other details of excretory system not observed; flame-cell formula not determined.

Description of metacercaria (based on 13 live encysted specimens): Metacercaria in subspherical thin-walled cyst, $238-320 \times 235-297(297 \times 278)$. Entire tegument covered with dense spines. Oral sucker subterminal, $50 \times$ 55 ; ventral sucker $44 \times 55$; prepharynx short; pharynx 18 $\times 15$; oesophagus long; caeca short. Reproductive system well-developed. Testes lateral, oval, symmetrical; left testis $77-85 \times 49-60(82 \times 55 ; \mathrm{n}=4)$; right testis $80-83 \times 58-60$ $(81 \times 59 ; n=3)$. Cirrus-sac absent. Seminal vesicle intercaecal in mid-body. Phallus large, muscular, sucker-like, spherical, with polygonal ejaculatory duct and muscular walls, sinistral to ventral sucker. Ovary dextral, transversely oval, $38-45 \times 61-70(41 \times 64 ; n=3)$. Vitellarium in two symmetrical clusters of few large follicles, at testicular level in hindbody. Excretory vesicle V-shaped, filled with large granules.

First intermediate host: Posticobia brazieri (Smith) (Gastropoda: Tateidae).

L o c a li ty: Moggill Creek, Queensland, Australia.

Prevalence of emergence: 1 of 2160.

Second intermediate host: Cherax dispar Reik (De- 


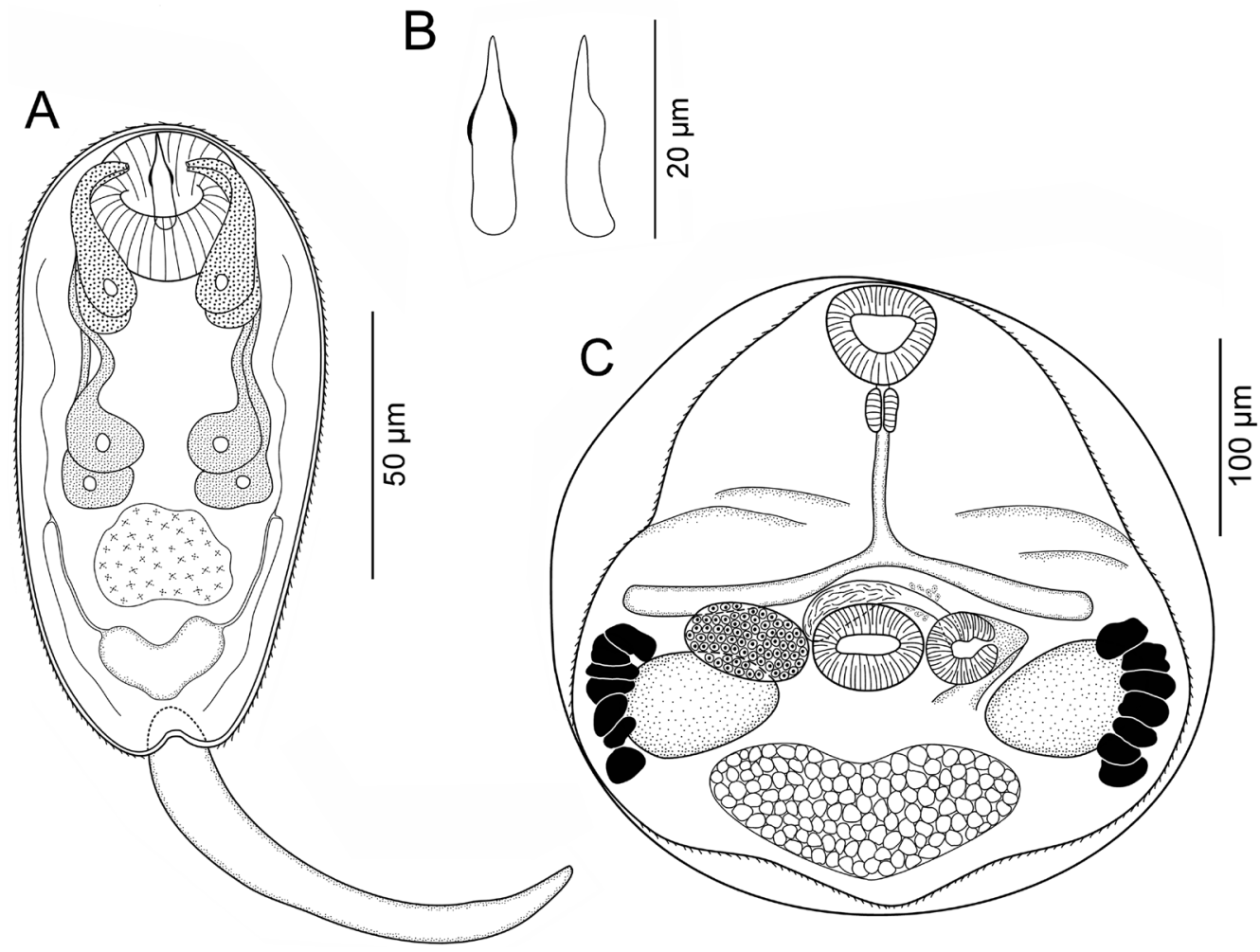

Fig. 2. Microphallus minutus Johnston, 1948. A-cercaria from Posticobia brazieri (Smith), ventral view; B - stylet, ventral and lateral view; C - metacercaria from Cherax dispar Reik.

capoda: Parastacidae).

L o c a lity: Moggill Creek, Queensland, Australia.

Prevalence: 1 of 1 .

Representative sequences: Cercaria KT355823 (28S

rDNA), KT355829 (ITS2), metacercaria KT355822 (28S

rDNA), KT355828 (ITS2).

Remarks. The metacercapariae from our collection exhibit features typical for the Microphallinae Ward, 1901, in particular the absence of a cirrus-sac and the seminal vesicle and pars prostatica lying free in the parenchyma (Deblock 2008).

Seven species of Microphallus have been reported in Australia and three of them are known from second intermediate hosts (Table 2). The present metacercaria is strongly consistent with the morphological description of M. minutus by Shimazu and Pearson (1991) from C. dispar in the shape and structure of the cyst, whereby the outer layer in young metacercariae is very thick. Although no metrical data for the metacercariae are available, we compared the encysted metacercariae with a well-developed reproductive system with the metrical data given for adults of M. minutus by Shimazu and Pearson (1991) (see Table 3). Comparisons revealed that the metrical data of our description fall within the range for M. minutus, but our material exhibits slightly lower limits for the size of the pharynx $(18 \times 15 \mu \mathrm{m} v s 22-24 \times 16-17 \mu \mathrm{m})$ and the width of the ovary $(38-45 \mu \mathrm{m} v s 48-80 \mu \mathrm{m})$. Since the thick outer layer of the cyst was included in measurements by Shimazu and Pearson (1991), the size of the cyst differs from our data in distinctly higher upper limits $(238-320 \mu \mathrm{m} \times 235-297 \mu \mathrm{m}$ vs 310-540 $\mu \mathrm{m} \times 290-540 \mu \mathrm{m})$.

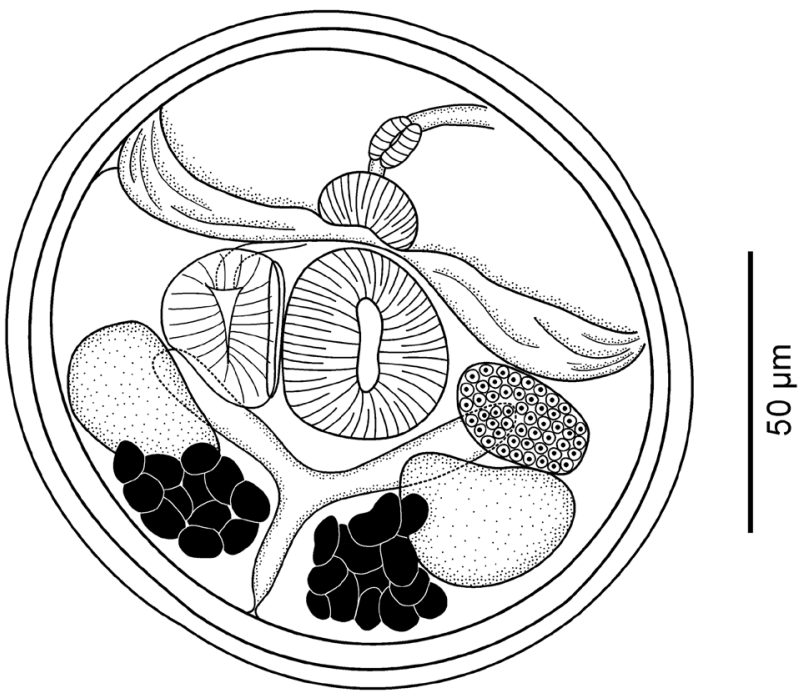

Fig. 3. Microphallidae gen. sp., metacercaria from Posticobia brazieri (Smith).

The species was described based on material from Hydromys chrysogaster Geoffroy in the Murray River (South Australia) by Johnston (1948) who suggested Cherax destructor Clark as potential second intermediate host of M. minutus. Deblock and Pearson (1969) reported M. minutus from H. chrysogaster in Moggill and Palmwood, Queensland, Australia. Shimazu and Pearson (1991) found metacercariae of this species in $C$. dispar from the Brisbane River (Queensland), confirming the suggestion of Johnston (1948). Notably, P. brazieri has been reported widely in eastern Australia (Clark 2009), including from 


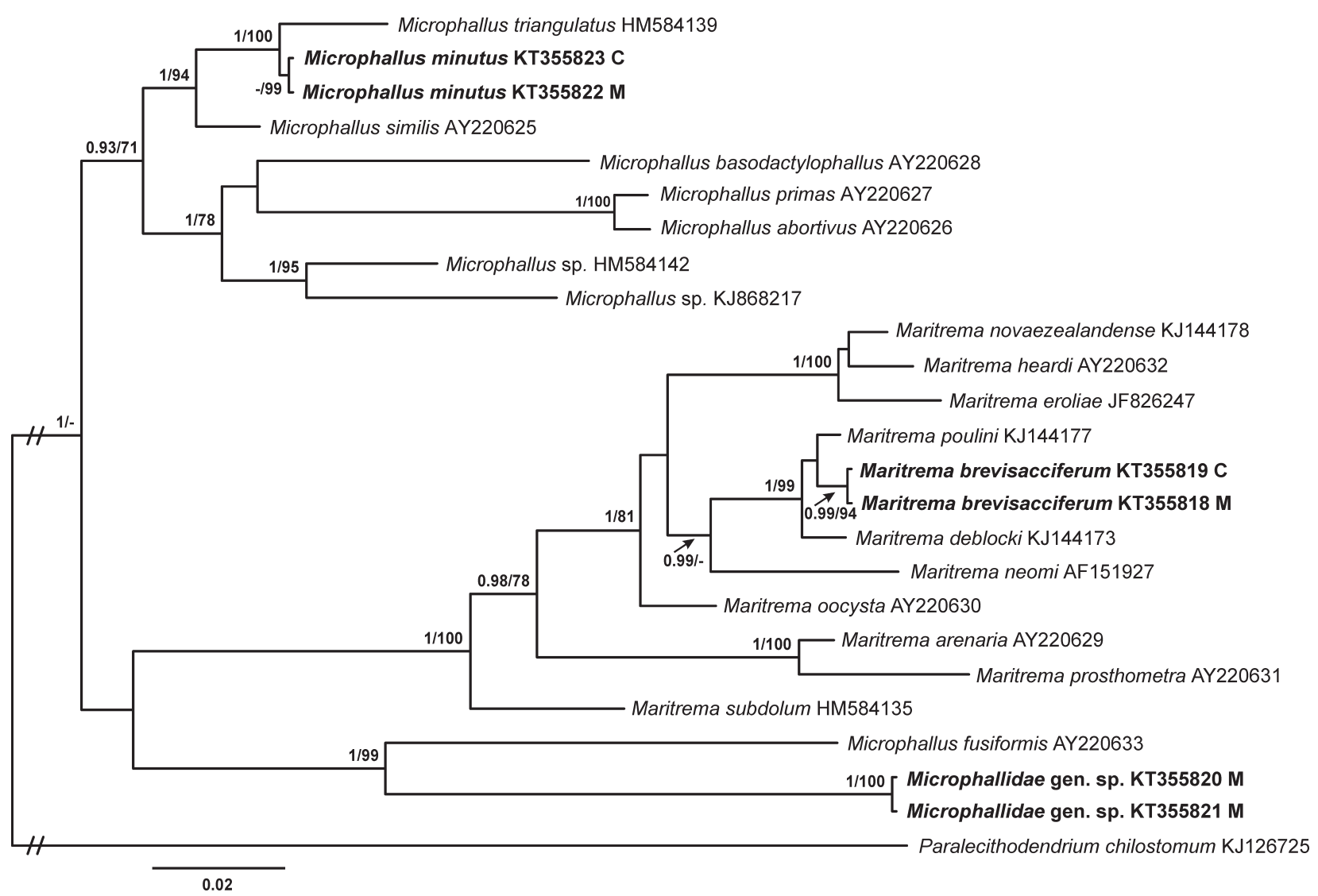

Fig. 4. Phylogenetic relationships among the taxa of the Microphallidae resulting from Bayesian inference (BI) and Maximum likelihood (ML) analyses based on partial 28S rDNA data. Nodal support associated with the branches are listed as BI posterior probability/ ML bootstrap support; support values lower than 0.90 (BI) and 70 (ML) are not shown. The scale-bar indicates the expected number of substitutions per site. Sequences obtained in the present study indicated by bold font. Abbreviations: C - cercaria; M - metacercaria.

the type locality of M. minutus, Tailem Bend on the Murray River in South Australia; presumably it is also involved in transmission there.

The sequences of cercarial isolates from the snail $P$. brazieri and metacercarial isolates from $C$. dispar were identical for each of the $28 \mathrm{~S}$ and ITS2 rDNA regions. We, therefore, consider that they belong to the same species. This is the first report and description of the cercaria of M. minutus.

\section{Microphallidae gen. sp.}

Fig. 3

Description of metacercaria (preliminary description based on 24 live encysted specimens from $P$. brazieri from Fairnie Brook - 19 and C. indistincta from Churchbank Weir -5$)$ : Metacercaria in subspherical cyst, 115-129 $\times$ $105-123(123 \times 114)$. Cyst wall consisting of two hyaline layers. Entire tegument covered with dense spines. Oral sucker subterminal; ventral sucker large, muscular. Reproductive system well-developed. Testes lateral, oval, symmetrical. Structure resembling phallus large, almost equal to ventral sucker in size, sinistral to ventral sucker. Vitellarium in two symmetrical clusters of few large follicles, post-testicular in hindbody. Excretory vesicle Y-shaped.

Second intermediate host: Posticobia brazieri

(Smith) (Gastropoda, Tateidae), Caridina indistincta Calman
(Decapoda, Atyidae).

L o c a lity: Fairnie Brook and Churchbank Weir, Queensland, Australia.

Prevalence : C. indistincta $8 \%$ (Churchbank Weir).

Representative sequences: KT355820, KT355821 (28S rDNA), KT355826, KT355827 (ITS2).

Remarks. Further study on the morphology of this species is required. This species may well be closely related to, or even conspecific with, Microphallus sp. ('livelyi') of Hechinger (2012) from Potamopyrgus antipodarum from New Zealand, which also develops directly to metacercariae in the tissues of the snail. Abbreviation of microphallid life cycles by formation of metacercariae in the first intermediate host is common (see Galaktionov and Skirnisson 2007). However, in addition to such development in the present case, our recording of genetically and morphologically identical metacercariae from atyid shrimps shows that the present form has two potential pathways of transmission. We are unaware of previous reports of such a dichotomy.

\section{Phylogenetic analysis}

The specimens of $M$. brevisacciferum, M. minutus and Microphallidae gen. sp. showed no intraspecific sequence variability for either the $28 \mathrm{~S}$ or ITS2 rDNA regions. The alignment used in the phylogenetic analysis included the 
newly-generated partial 28S rDNA sequences for the three species obtained during this study together with sequences for 18 representatives of the Microphallidae available on GenBank and the lecithodendriid outgroup Paralecithodendrium chilostomum (Table 1). The final alignment was 1166 bp long including several introduced gaps. BI and ML analyses produced fully resolved phylogenetic trees comprising three major clades with strong support (Fig. 4). The first clade included nine species of the genus Microphallus. Sequences for M. minutus generated during this study clustered with strong support together with other species of Microphallus. The second strongly supported clade included 12 species of Maritrema with which the new sequences for $M$. brevisacciferum formed a monophyletic lineage associated with strong support with sequences for Maritrema spp. from a freshwater snail P. antipodarum and a bird Anas platyrhynchos (Linnaeus), described from New Zealand (Presswell et al. 2014).

Our phylogenetic analyses clearly indicated that Microphallidae gen. sp. forms a third distinct clade, together with a species identified as Microphallus fusiformis Reimer, 1963, sister to, or even a member of Maritrema (see below). Obtaining rDNA sequences from additional representatives of the Microphallidae would be essential for clarifying its generic affiliation.

\section{DISCUSSION}

Using combined morphological and molecular characteristics, we were able to establish links between cercariae and metacercariae of Maritrema brevisacciferum and Microphallus minutus for which complete life cycles were previously unknown; we provide the first descriptions of their cercariae. M. minutus has a three-host life cycle with cercariae developing in the tateid snail Posticobia brazieri and metacercariae encysting in parastacid crayfish, Cherax dispar. Adults develop in mammals, water rats (Hydromys chysogaster; natural host) and mice (experimental host). Cercariae of $M$. brevisacciferum also develop in P. brazieri and metacercariae develop in atyid shrimps, Caridina indistincta; the natural definitive host is unknown. Microphallids frequently lack strict specificity, with final hosts being dependent on trophic habits of predators for crustacean or, occasionally, molluscan second intermediate hosts (Deblock 2008); thus, the natural host of this species is difficult to predict. For both species the morphology of the cercariae does not differ significantly from that of other congeners.

The new sequences of the metacercariae of Microphallidae gen. sp. formed a well-supported clade within the Microphallidae, but not with species of Microphallus and Maritrema. The position of this species as a sister group to the Maritrema clade is not unexpected from the viewpoint of morphology. Microphallidae gen. sp. differs from species of Maritrema in the absence of cirrus-sac and in having the vitellarium in two post-testicular clusters of follicles in the hindbody. Based on phylogenetic analysis, this species appeared closely related to Microphallus fusiformis, but the identification of the material sequenced as M. fusiformis is unclear. The annotation in GenBank (Tk- ach et al. 2003) indicates 'chick eggs' as a 'laboratory host' and the United Kingdom as the country of provenance for the isolate. However, the sequence has been published as Microphallidae gen. sp. from Hydrobia ulvae (Pennant) in Northern Ireland by Tkach et al. (2003) and as M. fusiformis with the same provenance by Olson et al (2003) (see table 1 in both papers). The separation of this species from the remaining species of Microphallus in its own genus-level group demonstrated in our phylogenetic analyses has been reported previously (Olson et al. 2003, Tkach et al. 2003, Presswell et al. 2014). Therefore, we prefer to consider this result with caution until the re-identification of the material sequenced by Tkach et al. (2003) and Olson et al. (2003).

Life cycles of microphallids take place in brackish, marine or fresh waters, in decreasing order of frequency (Deblock 2008). The vast majority of known first intermediate hosts are littoral gastropods of the genera Hydrobia Hartmann and Littorina Férussac (see Belopol'skaya 1963, Deblock 1980, Galaktionov and Bustnes 1999, Granovich et al. 2000, Galaktionov et al. 2012). At least 31 microphallid species are currently known to develop in fresh water. They are mainly reported from second intermediate hosts and described from experimentally obtained adults (Table 4). In our analyses, three species of Maritrema that develop in freshwater invertebrates (Maritrema neomi Tkach 1998, M. brevisacciferum and Maritrema poulini), clustered in a strongly supported subclade nested among species developing in marine invertebrates; the life cycle of the fourth species in the subclade, Maritrema deblocki Presswell, Blasco-Costa et Kostadinova, 2014, remains unknown.

Posticobia brazieri has traditionally been included in the Hydrobiidae Stimpson (e.g. Clark 2009). However, we have here recognised it as belonging to the Tateidae in line with the phylogenetic analysis of 'rissooid' gastropods proposed by Wilke et al. (2013). This analysis does not specifically refer to $P$. brazieri, but it is clear that the scope of the family is thought to incorporate it. The report of three species of the Microphallidae from P. brazieri here adds to the remarkable list of trematodes known to infect this species in southern Queensland. Further records include two species of the Aporocotylidae Odhner, 1912 (only one named - Nolan and Cribb 2004), one species of the Cryptogonimidae Ward, 1917, one species of the Haploporidae Nicoll, 1914, two species of the Lepocreadiidae Odhner, 1905, one species of the Opecoelidae Ozaki, 1925 and one species of the Transversotrematidae Wittenberg, 1944 (see Cribb 1985, 1986, 1988a, Martin 1973, Watson 1984). In addition, Cribb (1988b) mentioned the occurrence of two cystophorous cercariae (Hemiuroidea Looss, 1899) and in the present study we have also detected infections of at least one pronocephaloid, one renicolid and one psilostomid. We are thus aware of a minimum of 16 trematode species infecting P. brazieri. Among at least the Pronocephaloidea Looss, 1899 and Haploporidae, it seems likely that more than one species is involved.

Two aspects of this richness are noteworthy. First, as the only rissooid gastropod that we have seen in fresh water in south-east Queensland, it is clear that this species, 


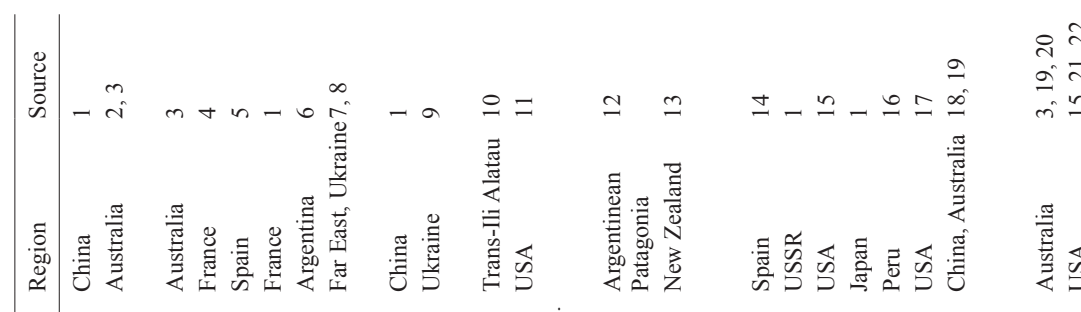

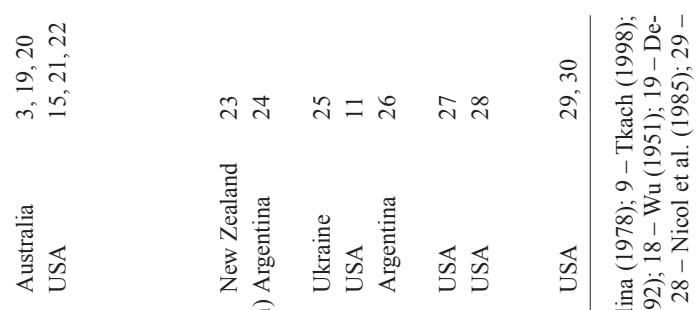

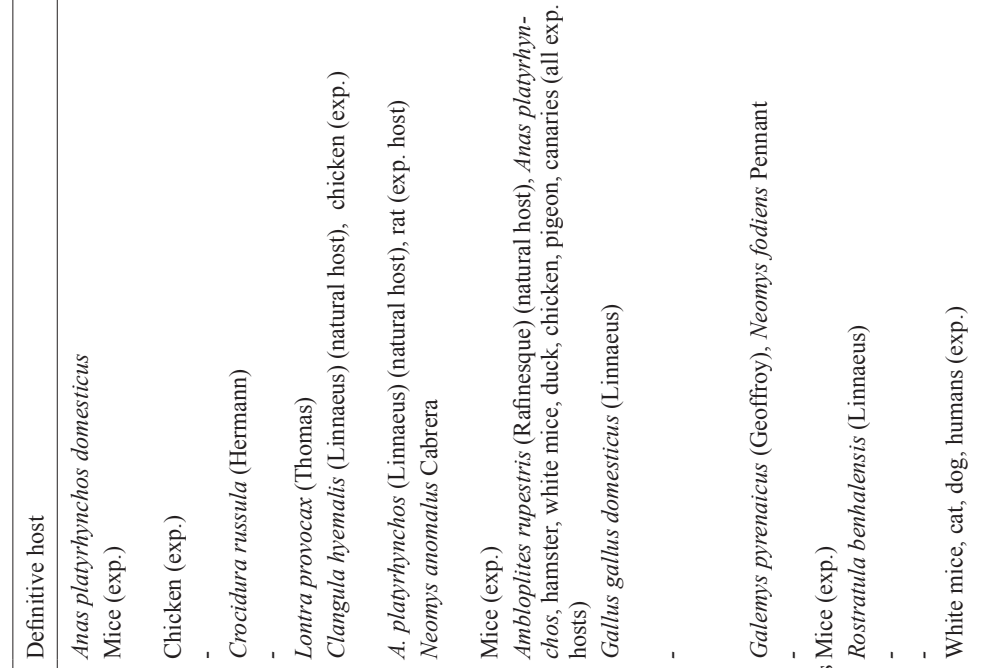
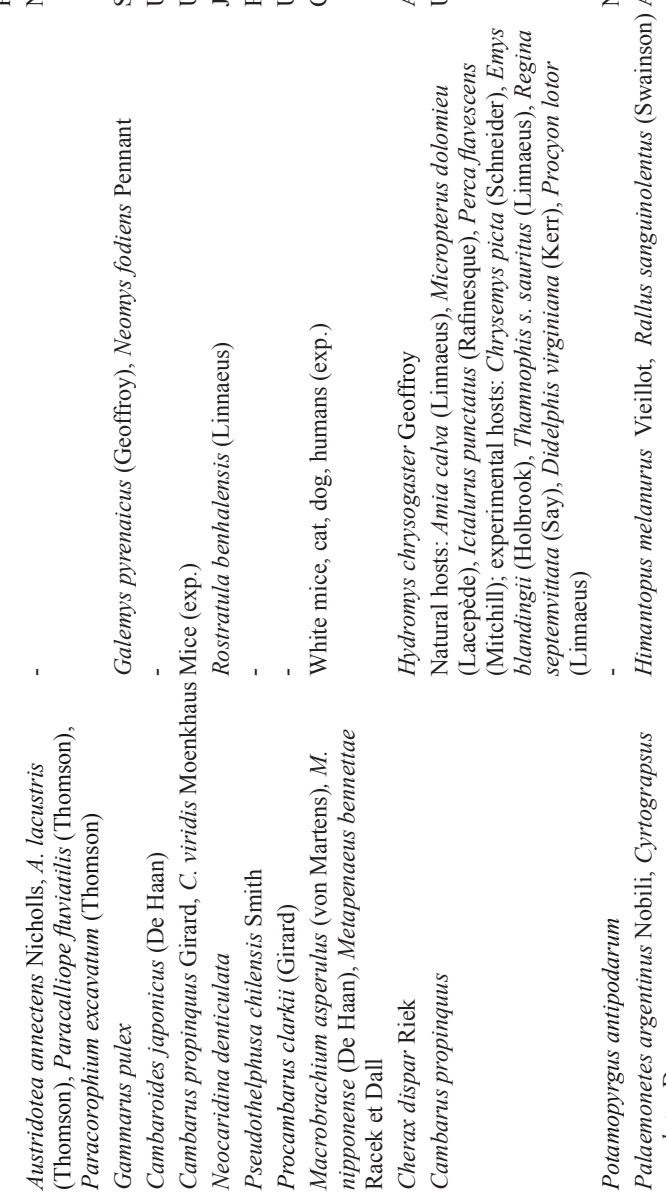

MIII

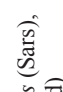

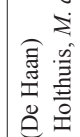

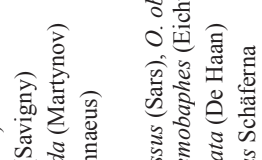

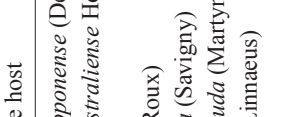
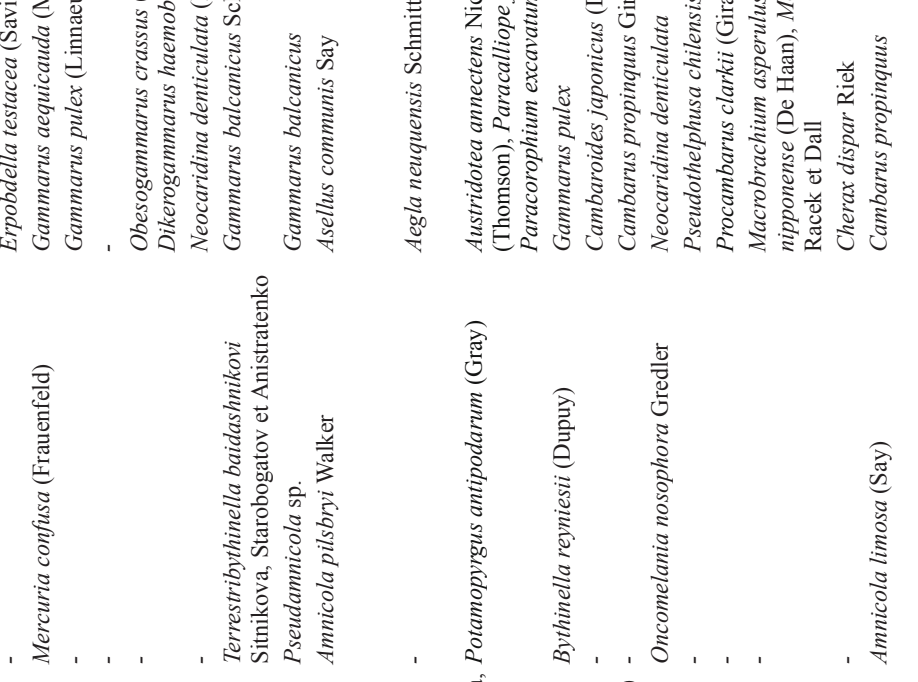

बू

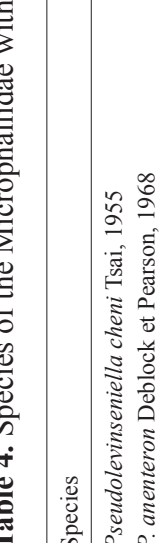

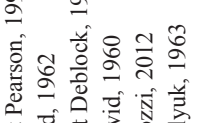

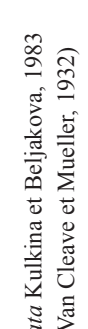

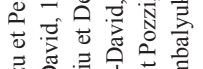

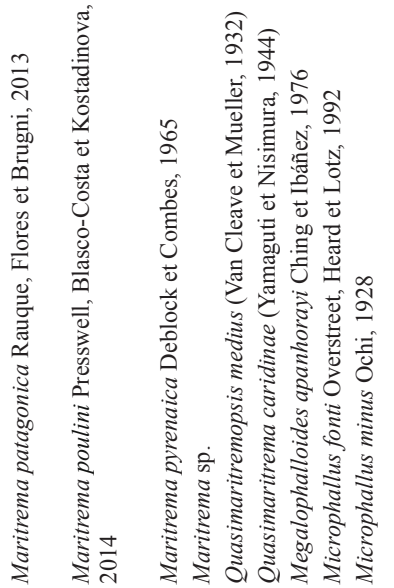
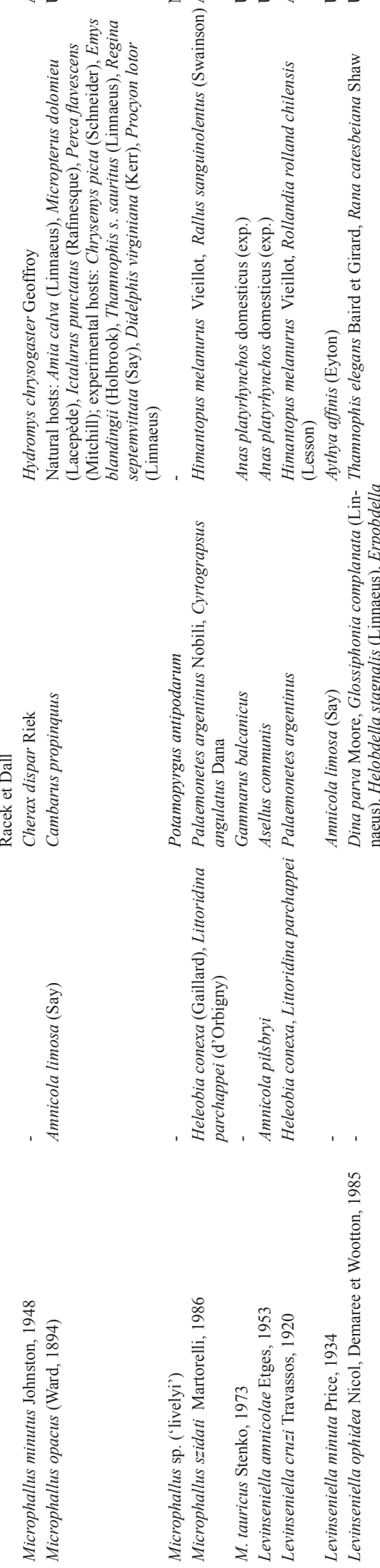

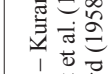

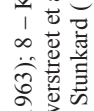

ठูँ

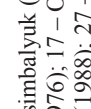

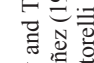

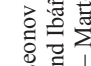

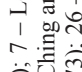

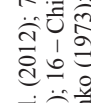

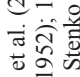

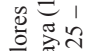

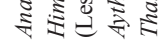


which often occurs in huge densities, plays a pivotal role in a wide variety of the trematode cycles in the region. Secondly, we note that this role is also filled by rissooids elsewhere. Hechinger (2012) summarised knowledge of 20 species of trematodes that infect the New Zealand tateid, $P$. antipodarum. The parallels with the fauna of $P$. brazieri are striking. Both harbour Aporocotylidae (both two species), Cryptogonimidae, Lepocreadiidae, Microphallidae, Opecoelidae, Pronocephaloidea, and (possibly) Haploporidae and Psilostomidae Looss, 1900. The only family level distinctions between the two are the strigeid and 'lecithodendriid-like families' in $P$. antipodarum and the presence of hemiuroid, renicolid and transversotrematids in $P$. brazieri. Further study may increase the level of similarity. Similarly, Deblock (1978) summarised the fauna of three species of Hydrobia from salt marshes and estuaries in France; he reported a remarkable 40 trematode species from 14 families. Microphallids occupy a central position in the list with 12 species. Species of Hydrobia are currently known as an intermediate host for about 19 species of the Microphallidae (Deblock 1978, 1980, Field and Irwin 1999, Bartoli and Gibson 2007, Bordalo et al. 2011).

Acknowledgements. The authors thank Russell Q.-Y. Yong and Pablo E. Diaz, who kindly provided assistance with the processing of snails. This study was supported in part by the European Union Structural Funds project 'Postdoctoral Fellowship Implementation in Lithuania' (VP1-3.1-ŠMM-01-V-02-004) and the Czech Science Foundation (project ECIP P505/12/G112) to OK and by Australian Biological Resources Study funding to THC and SCC.

\section{REFERENCES}

Al-Kandari W.Y., Al-Bustan S.A., Alnaqeeb M. 2011: Ribosomal DNA sequence characterization of Maritrema $\mathrm{cf}$. eroliae Yamaguti, 1939 (Digenea: Microphallidae) and its life cycle. J. Parasitol. 97: 1067-1074.

Anderson G.R., BARKer S.C. 1998: Inference of phylogeny and taxonomy within the Didymozoidae (Digenea) from the second internal transcribed spaces (ITS2) of ribosomal DNA. Syst. Parasitol. 41: 87-94.

Bartoli P., Gibson D.I. 2007: Synopsis of the life cycles of Digenea (Platyhelminthes) from lagoons of the northern coast of the western Mediterranean. J. Nat. Hist. 41: 1553-1570.

Belopol'skaya M.M. 1952: [Family Microphallidae.] In: K.I. Skrjabin (Ed.), Osnovy Trematodologii, Volume 6. Izdatel'stvo Akademii Nauk SSSR, Moskva, pp. 619-756. (In Russian.)

Belopol'skaya M.M. 1963: [Family Microphallidae.] In: K.I. Skrjabin, (Ed.), Osnovy Trematodologii, Volume 21. Izdatel'stvo Akademii Nauk SSSR, Moskva, pp. 260-502. (In Russian.)

Bordalo M.D., Ferreira S.M., Jensen K.T., Pardal M.A. 2011: Trematode fauna of Hydrobia ulvae (Gastropoda: Prosobranchia) in a eutrophic temperate estuary. J. Mar. Biol. Ass. UK 91: 913-921.

Bowles J., Hope M., Tiu W.U., Liu X.S., McManus D.P. 1993: Nuclear and mitochondrial genetic markers highly conserved between Chinese and Philippine Schistosoma japonicum. Acta Trop. 55: 217-229.

CANNON L.R.G. 1978: Marine cercariae from the gastropod Cerithium moniliferum Kiener at Heron Island, Great Barrier Reef. Proc. R. Soc. Queensl. 89: 45-57.

Casanova J.C., Villa M., Montoliu I. 1998: First record of Maritrema pyrenaica (Digenea: Microphallidae) in Spain (Western Pyrenees) in its intermediate hosts. Folia Parasitol. 45: 251-252.

Caveny B.A., Etges F. 1971: Life history studies of Microphallus opacus (Trematoda: Microphallidae). J. Parasitol. 57: 1215-1221.

CHING L.H., IBAÑez N. 1976: Description of Megalophalloides apanhorayi gen. et sp. n. (Trematoda, Microphallidae) from mice and fresh water crabs of Peru. Can. J. Zool. 54: 1438-1442.

Clark S.A. 2009: The genus Posticobia (Mollusca: Caenogastropoda: Rissooidea: Hydrobiidae S.L.) from Australia and Norfolk Island. Malacologia 51: 319-341

CRIBB T.H. 1985: The life cycle and biology of Opecoelus variabilis sp. nov. (Digenea: Opecoelidae). Aust. J. Zool. 33: 715-728.

CRibB T.H. 1986: The life cycle and morphology of Stemmatostoma pearsoni gen. et sp. nov., with notes on the morphology of Telogaster opisthorchis Macfarlane (Digenea: Cryptogonimidae). Aust. J. Zool. 34: 279-304.

Cribi T.H. 1988a: Life cycle and biology of Prototransversotrema steeri Angel, 1969 (Digenea: Transversotrematidae). Aust. J. Zool. 36: 111-129.
CRIBB T.H. 1988b: Two new digenetic trematodes from Australian freshwater fishes with notes on previously described species. J. Nat. Hist. 22: 27-43.

Cribb T.H., Anderson G.R., Adlard R.D., Bray R.A. 1998: A DNA-based demonstration of a three-host life-cycle for the Bivesiculidae (Platyhelminthes: Digenea). Int. J. Parasitol. 28: 1791-1795.

Darriba D., Taboada G.L., Doallo R., Posada D. 2012: jModelTest 2: more models, new heuristics and parallel computing. Nat. Methods 9: 772.

Deblock S. 1978: Distribution géographique des cercaires parasites des mollusques du genre Hydrobia Hartman des côtes de France. Ann. Parasitol. Hum. Comp. 53: 577-593.

DeBLock S. 1980: Inventaire des trématodes larvaires parasites des mollusques Hydrobia (Prosobranches) des côtes de France. Parassitologia 22: 1-105.

Deblock S. 2008: Family Microphallidae Ward, 1901. In: R.A. Bray, D.I. Gibson and A. Jones (Eds.), Keys to the Trematoda. Volume 3. CABI, Wallingford, and Natural History Museum, London, pp. 451-492.

Deblock S., Canaris A. 1996: Microphallidae Trematoda: XLVIII. Quatre Maritrema du groupe Eroliae; parasites d'oiseaux australiens. Parasite 4: 357-361.

Deblock S., Canaris A.G. 1997: Contribution à l'étude des Microphallidae (Trematoda). XLIX. Espèces d'oiseaux de Tasmanie. Création de Rhyncostophallus n. g. Syst. Parasitol. 37: $13-19$

Deblock S., Pearson J. 1968: Contribution à l'étude des Microphallidés Travassos, 1920 (Trematoda). XV. De quelques espèces d'Australie dont Pseudospelotrema anenteron n. sp. Ann. Parasitol. Hum. Comp. 43: 457-465.

Deblock S., Pearson J.C. 1969: Contribution à l'étude des Microphallidae Travassos, 1920 (Trematoda) XVIII - De cinq Microphallus d'Australie dont deux nouveaux. Ann. Parasitol. Hum. Comp. 44: 391-414.

Deblock S., Williams A., Evans L.H. 1990: Contribution à l'étude des Microphallidae Travassos 1920 (Trematoda). Description de Thulakiotrema genitale n. gen., n. sp., métacercaire parasite de langoustes australiennes. Bull. Mus. Hist. Nat. 12: 563-576.

ETGES F.J. 1953: Studies on the life histories of Maritrema obstipum (Van Cleave and Mueller, 1932) and Levinseniella amnicolae $\mathrm{n}$. sp. (Trematoda: Microphallidae). J. Parasitol. 39: 643-662.

Field L.C., Irwin S.W.B. 1999: Digenean larvae in Hydrobia ulvae from Belfast Lough (Northern Ireland) and the Ythan Estuary (north-east Scotland). J. Mar. Biol. Ass. UK 79: 431-435.

Flores V.R., Brugni N.L., Pozzi C.M. 2012: A new microphallid (Digenea) species from Lontra provocax (Mammalia: Mus- 
telidae) from freshwater environments of northwestern Patagonia (Argentina). J. Parasitol. 98: 992-994.

Galaktionov K.V., Blasco-Costa I., Olson P.D. 2012: Life cycles, molecular phylogeny and historical biogeography of the 'pygmaeus' microphallids (Digenea: Microphallidae): widespread parasites of marine and coastal birds in the Holarctic. Parasitology 139: 1346-1360.

Galaktionov K.V., Bustnes J.O. 1999: Distribution patterns of marine bird digenean larvae in periwinkles along the southern coast of the Barents Sea. Dis. Aquat. Org. 37: 221-320.

Galaktionov K.V., Skirnisson K. 2007: New data on Microphallus breviatus Deblock et Maillard, 1975 (Microphallidae: Digenea) with emphasis on the evolution of dixenous life cycles of microphallids. Parasitol. Res. 100: 963-971.

Gracenea M., Montoliu J., Deblock S. 1993: Contribution à l'étude des Microphallidae Travassos, 1920 (Trematoda). XLV. Description de Maritrema feliui n. sp., parasite des musaraignes en Espagne. Ann. Parasitol. Hum. Comp. 68: 76-81.

Granovitch A.I., Sergievsky S.O., Sokolova I.M. 2000: Spatial and temporal variation of trematode infection in coexisting populations of intertidal gastropods Littorina saxatilis and $L$. obtusata in the White Sea. Dis. Aquat. Org. 41: 53-64.

Guindon S., Dufayard J.F., Lefort V., Anisimova M., HordIJK W., Gascuel O. 2010: New algorithms and methods to estimate maximum-likelihood phylogenies: assessing the performance of PhyML 3.0. Syst. Biol. 59: 307-321.

Hall T.A. 1999: BioEdit: a user-friendly biological sequence alignment editor v. 5.0.9. Nucleic Acids Symp. Ser. 41: 95-98.

Hechinger R.F. 2012: Faunal survey and identification key for the trematodes (Platyhelminthes: Digenea) infecting Potamopyrgus antipodarum (Gastropoda: Hydrobiidae) as first intermediate host. Zootaxa 3418: 1-27.

Hickman V.V. 1955: On Maritrema ornithorhynchi sp. n., a new trematode from the monotreme, Ornithorhynchus anatinus Shaw, with a key to the genus Maritrema Nicoll. Rev. Ibérica Parasitol. 181-191.

Johnston T.H. 1948: Microphallus minutus, a new trematode from the Australian water rat. Rec. South. Aust. Mus. 9: 93-100.

Kudlai O., Stunzenas V., Tкасн V. 2015: The taxonomic identity and phylogenetic relationships of Cercaria pugnax and Cercaria helvetica XII (Digenea: Lecithodendriidae) based on morphological and molecular data. Folia Parasitol. 62: 003.

Kulkina L.V., Beljakova Yu.V. 1983: [Life cycle of Maritrema parainusitata sp. n. (Trematoda: Microphallidae).] Parazitologiya 17: 272-277. (In Russian.)

Kurandina D.I.: 1978: [On the finding of Maritrema inusitata Leonov et Cimbaluk, 1963 (Trematoda: Microphallidae) in amphipods in the basin of the River Dnipro.] In: Problemy Hydroparazililogii. Naukova dumka, Kiev, pp. 123-125. (In Russian.)

Leonov V.A., Tsimbalyuk A.K. 1963: [A new species of trematode of Maritrema inusitata sp. $n$. from the long-tailed duck from Kamchatka.]. Vestnik Leningradskogo Universiteta 1: 145-149. (In Russian.)

Littlewood D.T.J., Curini-Galletti M., Herniou E.A. 2000 The interrelationships of Proseriata (Platyhelminthes: Seriata) tested with molecules and morphology. Mol. Phylogenet. Evol. 16: 449-466.

Lotz J.M., Corkum K.C. 1983: Studies on the life history of Sogandaritrema progeneticus (Digenea: Microphallidae). J. Parasitol. 69: 918-921.

Martin W.E. 1973: Life history of Saccocoelioides pearsoni $\mathrm{n} . \mathrm{sp}$ and the description of Lecithobotrys sprenti $\mathrm{n}$. sp. (Trematoda: Haploporidae). Trans. Am. Microsc. Soc. 92: 80-95.

Martorelli S.R. 1986a: Estudio sistemático y biológico de un digeneo perteneciente a la familia Microphallidae Travassos, 1920. I: Microphallus szidati sp. nov. parásito intestinal de Rallus sanguinolentus sanguinolentus (Aves: Rallidae) e Himantopus melanurus (Aves: Recurvirostridae). Rev. Iber. Parasitol. 46: 373-378.
Martorelli S.R. 1986b: Estudio sistemático y biológico de un digeneo perteneciente a la familia Microphallidae Travassos, 1920 II: desarrollo del ciclo biológico de Microphallus szidati en dos ambientes de condiciones ecológicas diferentes. Rev. Iber. Parasitol. 46: 378-385.

Martorelli S.R. 1988: El ciclo biológico de Levinseniella cruzi Travassos, 1920 (Digenea, Microphallidae) parásito de los ciegos cólicos de Rollandia rolland chilensis (Aves, Podicipedidae) e Himantopus melanurus (Aves, Recurvirostridae). Iheringia 68: 49-62.

Mawson P.M., Angel L.M., Edmonds S.J. 1986: A checklist of helminths from Australian birds. Rec. South Aust. Mus. 19: 219-325.

Miller M.A., Pfeiffer W., Schwartz T. 2010: Creating the CIPRES Science Gateway for inference of large phylogenetic trees. Proceedings of the Gateway Computing Environments Workshop (GCE), 14 November, New Orleans, Louisiana, pp. $1-8$.

Nicol J.T., Demaree R. JR., Wootton D.M. 1985: Levinseniella (Monarrhenos) ophidea sp. n. (Trematoda: Microphallidae) from the western garter snake, Thamnophis elegans and the bullfrog, Rana catesbeiana. Proc. Helminthol. Soc. Wash. 52: 180-183.

Nolan M.J., Cribi T.H. 2004: The life cycle of Paracardicoloides yamagutii Martin, 1974 (Digenea: Sanguinicolidae). Folia Parasitol. 51: 320-326.

O’Dwyer K., Blasco-Costa I., Poulin R., Faltýnková A. 2014: Four marine digenean parasites of Austrolittorina spp. (Gastropoda: Littorinidae) in New Zealand: morphological and molecular data. Syst. Parasitol. 89: 133-152.

Olson P.D., Cribb T.H., Tkach V.V., Bray R.A., Littlewood D.T.J. 2003: Phylogeny and classification of the Digenea (Platyhelminthes: Trematoda). Int. J. Parasitol. 33: 733-755.

Overstreet R.M., Heard R.W., Lotz J.M. 1992: Microphallus fonti sp. n. (Digenea: Microphallidae) from the red swamp crawfish in southern United States. Mem. Inst. Oswaldo Cruz. 87: $175-178$.

Presswell B., Blasco-Costa I., Kostadinova A. 2014: Two new species of Maritrema Nicoll, 1907 (Digenea: Microphallidae) from New Zealand: morphological and molecular characterisation. Parasitol. Res. 113: 1641-1656.

Rambaut A. 2012: FigTree v. 1.4. Molecular evolution, phylogenetics and epidemiology. Edinburgh, UK: University of Edinburgh, Institute of Evolutionary Biology. http://tree.bio.ed.ac.uk/ software/figtree/, 12/2012.

RAUSCH R. 1947: Some observations on the host relationships of Microphallus opacus (Ward, 1894) (Trematoda: Microphallidae). Trans. Am. Microsc. Soc. 66: 59-63.

Ronquist F., Teslenko M., Van Der Mark P., Ayres D.L., Darling A., Höhna S., Larget B., Liu L., Suchard M.A., Huelsenbeck J.P. 2012: MrBayes 3.2: Efficient Bayesian phylogenetic inference and model choice across a large model space. Syst. Biol. 61: 539-542.

Rauque C.A., Flores V.R., Brugni N.L. 2013: Maritrema patagonica n. sp. (Digenea: Microphallidae) cultured from metacercariae from freshwater anomuran, Aegla spp. (Decapoda: Aeglidae), in Patagonia. Comp. Parasitol. 80: 196-202.

Sambrook J., Russell D.W. 2001: Molecular Cloning: a Laboratory Manual. Cold Spring Harbor Laboratory Press, Cold Spring Harbor, 2100 pp.

Shimazu T., Pearson J. 1991: Adults and metacercariae of three microphallid trematodes, including a new species of the genus Maritrema from Queensland, Australia. Jpn. J. Zool. 40: 533541.

Sмiтн S.J. 1974: Three new microphallid trematodes from Tasmanian birds. Pap. Proc. R. Soc. Tasmania 107: 197-205.

SмiтH S.J. 1983: Three new species and a new record of microphallid trematodes from Tasmania, with observations on their in vitro development. Pap. Proc. R. Soc. Tasmania 117: 105-123. 
SNyder S.D., TKaCH V.V. 2001: Phylogenetic and biogeographical relationships among some holarctic frog lung flukes (Digenea: Haematoloechidae). J. Parasitol. 87: 1433-1440.

Sogandares-Bernal F. 1962: Microphallus progeneticus, a new apharyngeate progenetic trematode (Microphallidae) from the dwarf crayfish, Cambarellus puer, in Louisiana. Tulane Stud. Zool. 9: 319-322.

Stenko R.P. 1973: [Microphallus tauricus sp. n. (Microphallidae Travassos, 1920), a new species of trematode from the Crimea.] Parazitologiya 7: 513-517. (In Russian.)

Stunkard H.W. 1958: The morphology and life-history of Levinseniella minuta (Trematoda: Microphallidae). J. Parasitol. 44: 225-229.

Timon-David J. 1962: Une métacercarire du genre Maritrema Nicoll (Trematoda, Digenea, Microphallidae) parasite de 1'hirudinée Erpobdella testacea (Sav.). Bull. Soc. Zool. France 87: 559-565.

TKACH V.V. 1998: Maritrema neomi n. sp. (Digenea: Microphallidae) from water shrews (Neomys). J. Parasitol. 84: 846-849.
TKach V.V., Littlewood D.T.J., Olson P.D., Kinsella J.M., Swiderski Z. 2003: Molecular phylogenetic analysis of the Microphalloidea Ward, 1901 (Trematoda: Digenea). Syst. Parasitol. 56: $1-15$.

Tkach V.V., Pawlowski J., Mariaux J. 2000: Phylogenetic analysis of the suborder Plagiorchiata (Platyhelminthes, Digenea) based on partial lsrDNA sequences. Int. J. Parasitol. 30: 83-93.

WATson R.A. 1984: The life cycle and morphology of Tetracerasta blepta gen. et sp. nov. and Stegodexamene callista sp. nov. (Trematoda: Lepocreadiidae) from the long-finned eel, Anguilla reinhardtii Steindachner. Aust. J. Zool. 32: 177-204.

Wilke T., Haase M., Hershler R., Liu H.-P., Misof B., PonDER W. 2013: Pushing short DNA fragments to the limit: phylogenetic relationships of 'hydrobioid' gastropods (Caenogastropoda: Rissooidea). Mol. Phylogenet. Evol. 66: 715-736.

Wu K. 1951: Progenesis of Microphallus minus Ouchi in fresh water shrimps. Peking Nat. Hist. Bull. 19: 194-209.

Cite this article as: Kudlai O., Cutmore S.C., Cribb T.H. 2015: Morphological and molecular data for three species of the Microphallidae (Trematoda: Digenea) in Australia, including the first descriptions of the cercariae of Maritrema brevisacciferum and Microphallus minutus. Folia Parasitol. 62: 053. 